\title{
Association between the Use of Touchscreen Device and Child Development
}

\author{
Husada Tsalitsa Mardiansyah¹, Mira Irmawati ${ }^{2}$, Dwi Susanti ${ }^{3}$
}

${ }^{1}$ Faculty of Medicine, Universitas Airlangga, Surabaya, Indonesia.

${ }^{2}$ Department of Pediatrics, Faculty of Medicine, Universitas Airlangga, Surabaya, Indonesia.

${ }^{3}$ Department of Public Health and Preventive Medicine, Universitas Airlangga, Surabaya, Indonesia.

\section{A B S T R A C T}

Introduction: Early childhood development is related to sensitive period, a spesific period when a child is more easily stimulated by certain environmental stimulation. The right stimulation is needed to achieve good development. The intense use of touchscreen device is thought to potentially be a new form of stimulation that could affect child development. The aim of this study was to determine whether there is an association between the use of touchscreen device and child development.

Methods: The design of this study was observational analytic with cross-sectional approach. The sampling technique used in this study was cluster-sampling. Data collection was finished in October 2018 by interviewing the respondents and assessing child development using development pre-screening questionnaire (KPSP).

Results: Among 91 samples of this study, the majority (78.0\%) had actively operated touchscreen devices by themselves. The result of the Kruskal Wallis test gave a value of $p=0.398(p>0.05)$ with the mean rank of not at all 29.50 ; only watching 48,53; and operating 46.09 .

Conclusion: The use of touchscreen device is not significantly associated with children development. Further research needs to be conducted to uncover the effect of touchscreen device on child development.

\section{*Correspondence: irmawatimira@gmail.com}

JUXTA: Jurnal IImiah Mahasiswa Kedokteran Universitas Airlangga

p-ISSN: 1907-3623; e-ISSN: 2684-9453

DOI: $10.20473 /$ juxta.V12I12021.45-47

Open access under Creative Commons Attribution-ShareAlike 4.0 International License

(CC-BY-SA)

\section{ARTICLE INFO}

\section{Article history:}

Received 28 December 2020

Accepted 30 December 2020

\section{Keywords:}

Development,

Child,

Touchscreen. 


\section{Introduction}

Early childhood is often referred as the golden period. During this time, various basic growths and developments occur. Development consists of different and specific stages at each age. This is related to sensitive period, a specific period when a child is more easily stimulated by certain environmental stimulation because the development of the nervous system is sensitive to particular stimulation at that time. ${ }^{1}$ The right stimulation is needed so that the period can be optimized to achieve good development. Developmental delay at a certain stage will affect and determine the next stage of development. ${ }^{2}$

Recently, various things have been invented and developed. Among them is one of the results of technology advancement, touchscreen device. Nowadays, touchscreen device users are no longer of a certain age but have reached all the ages including children under five years old. ${ }^{3}$ Its easy usage and diverse features make touchscreen device favoured by children and used for various purposes. ${ }^{4}$ As the stimulation plays an important role in children development, ${ }^{2}$ the intense use of touchscreen devices is thought to potentially be a new form of stimulation that could affect child development. ${ }^{5}$

The aim of this study was to determine whether there is an association between the use of touchscreen device and child development.

\section{Methods}

The design of this study was observational analytic with cross-sectional approach. The population was children under five years old in Surabaya. The sample was obtained from some community health centers in Surabaya. The sampling technique used in this study was clustersampling. Data collection was finished in October 2018. The instruments used in this study were development prescreening questionnaire (KPSP) and interview sheet. The analysis was conducted using SPSS Statistics ${ }^{\circledR}$ 25.0. This study had been approved by the ethics committee of Faculty of Medicine Universitas Airlangga and got permission from the Health Office and BakesbangpolLINMAS of Surabaya.

\section{Results}

Among 91 samples of this study, the majority (78.0\%) had actively operated touchscreen devices by themselves (Table 1).

Table 1. Touchscreen usage.

\begin{tabular}{lll}
\hline Usage status & $\mathbf{n}$ & $\%$ \\
\hline Not at all & 3 & 3.3 \\
Only watching & 17 & 18.7 \\
Operating & 71 & 78.0 \\
\hline
\end{tabular}

The statistical test used in this study was Kruskal Wallis because the result of chi-square test did not meet the requirements, the number of cells that had an expected value of less than 5 was more than $20 \%$. The result of the Kruskal Wallis test gave a value of $p=0.398(p>0.05)$ with the mean rank of not at all 29.50; only watching 48.53; and operating 46.09 (Table 2).

Table 2. Kruskal Wallis test analysis result.

\begin{tabular}{llll}
\hline Variable & Standard significance value & $\mathbf{p}$ & Interpretation \\
\hline Touchscreen usage & 0.05 & 0.398 & Not significant \\
\hline
\end{tabular}

Mean rank of not at all 29.50; only watching 48,53; and operating 46.09

Statistically, there is no significant difference between the development of children who do not use, just watch, and operate touchscreen device by themselves. However, it is found that children who only watch the media through touchscreen device have the highest mean rank. It means the effects of the use of touchscreen device on child development on the 'only watching' group is bigger than other groups.

\section{Discussion}

Child development has a predictable pattern. ${ }^{2}$ The stages of development are specific according to the age. This is related to the rapid development of the brain in all domains in the first years of life. ${ }^{6}$ Although development can be predicted, the rate of development of each child is not similar. There are various factors that can affect the quality of child development. , 6-8 $^{2}$ One of the external factors that can affect child development is stimulation. Stimulation in the family such as toys, children's socialization, and interaction between mother and other family members are needed to achieve good development. ${ }^{2}$

Touchscreen devices are one of the products of technological advancement that have been used so much lately. ${ }^{3}$ Unlike other electronic media, touchscreen devices can be used for various purposes, such as viewing photos, listening to songs, watching videos, accessing the internet, and playing games. 5, 9, 10 These diverse features make the use of touchscreen devices very easy to find in everyday life. In addition, its easy usage, that is just by touching the device, allows the children to operate it. This is confirmed by the results of this study which shows that most children have actively operated touchscreen devices by themselves (Table 1).

According to the result of statistical tests that had been done in this study, it was found that statistically, the use of touchscreen devices is not significantly associated with child development $(p>0.05)$. This is similar to the findings 
of Clayton, et al. (2017) which showed that there is no significant cognitive development differences between children under three years old who used touchscreen devices and those who did not (CAT $99.6 \pm 19.5$ vs. 103.4 \pm 19.8 ; CLAMS $104.0 \pm 24.0$ vs. $113.5 \pm 26.2$ ).

However, from the results of the Kruskal Wallis test, it can be seen that the mean rank of the use of touchscreen devices of 'only watching' group was the highest (48.53) compared to other categories (not at all 29.50; operating 46.09). It means that the effect of using touchscreen devices on child development in the children who were 'only watching' was greater than other groups; and because the coding used in this study placed 'possible deviations' at the highest ordinal level, it can be interpreted that the tendency to experience possible developmental deviations in the children who were 'only watching' was greater than other groups.

The use of touchscreen device that is limited to just viewing/watching the media makes its use similar to the use of other electronic media such as television, DVD players, etc. Meanwhile, it is known through the previous studies that the use of electronic media, not including touchscreen devices, was found to have a negative impact on children. The use of electronic media in early childhood is associated with obesity, sleep problems, aggressive behavior, and attention problems in pre-school and school-aged children. ${ }^{11}$ Children who watch television with high doses are found to have language delays. ${ }^{12}$

The mean rank of children who were 'operating' the touchscreen which was lower than the children who were 'only watching' may be related to the findings of Bedford, et al. (2016), which showed that the use of touchscreen devices was positively correlated with child's fine motor development. ${ }^{13}$ However, since statistically these findings do not have a significant correlation, deeper research needs to be done to bring more convincing findings.

\section{Conclusion}

In this study, the use of touchscreen device is not significantly associated with children development. Further research that explores other variables on the use of touchscreen device needs to be conducted and developed seriously to uncover the effect of touchscreen device on child development. This is in a great need because the use of touchscreen device has become a trend that must be faced and it requires immediate response so the latent impact of its usage can be controlled.

\section{CONFLICT OF INTEREST}

The author stated there is no conflict of interest in this study.

\section{REFERENCES}

1. Leisman G, Mualem R and Mughrabi SK. The Neurological Development of the Child with the Educational Enrichment in Mind. Psicología Educativa. 2015; 21: 79-96. 2. Indonesia DKR. Pedoman Pelaksanaan Simulasi Deteksi dan Intervensi Dini Tumbuh Kembang Anak di Tingkat Pelayanan Kesehatan Dasar. Jakarta: Departemen Kesehatan Republik Indonesia, 2005.

3. Rideout V. The Common Sense Census: Media Use by Kids Age Zero to Eight. In: Robb MB, (ed.). San Francisco2017.

4. Sheehan KJ and Uttal DH. Children's Learning from Touch Screens: A Dual Representation Perspective. Frontiers in Psychology. 2016; 7: 1220.

5. Li C, Mendoza M and Milanaik R. Touchscreen Device Usage in Infants and Toddlers and Its Correlations with Cognitive Development. Pediatrics \& Health Research. 2018; 02.

6. Grantham-McGregor S, Cheung YB, Cueto S, et al. Developmental Potential in the First 5 Years for Children in Developing Countries. The Lancet. 2007; 369: 60-70.

7. Thomaidis L, Zantopoulos GZ, Fouzas S, Mantagou L, Bakoula $C$ and Konstantopoulos A. Predictors of Severity and Outcome of Global Developmental Delay without Definitive Etiologic Yield: A Prospective Observational Study. BMC Pediatrics. 2014; 14: 40.

8. Walker SP, Wachs TD, Gardner JM, et al. Child Development: Risk Factors for Adverse Outcomes in Developing Countries. Lancet (London, England). 2007; 369: 145-57.

9. Fajariyah S, Suryawan A and Atika A. Dampak Penggunaan Gawai terhadap Perkembangan Anak. Sari Pediatri. 2018; 20: 101.

10. Radliya NR, Apriliya S and Zakiyyah TR. Pengaruh Penggunaan Gawai terhadap Perkembangan Sosial Emosional Anak Usia Dini. Jurnal PAUD Agapedia. 1: 1-12. 11. Media Education. American Academy of Pediatrics. Committee on Public Education. Pediatrics. 1999; 104: 341-3.

12. Chonchaiya $W$ and Pruksananonda C. Television Viewing Associates with Delayed Language Development. Acta Paediatrica (Oslo, Norway : 1992). 2008; 97: 977-82. 13. Bedford R, Saez de Urabain IR, Cheung $\mathrm{CH}$, KarmiloffSmith A and Smith TJ. Toddlers' Fine Motor Milestone Achievement is Associated with Early Touchscreen Scrolling. Frontiers in Psychology. 2016; 7: 1108. 